http://dx.doi.org/10.1590/0102-311XCO071013

Gilberto Hochman

Casa de Oswaldo Cruz, Fundação Oswaldo Cruz, Rio de Janeiro, Brasil. hochman@fiocruz.br

\section{Saudades do futuro ou um sistema de saúde em tempos democráticos}

Efemérides são ocasiões para celebrações, reflexões e críticas. São oportunidades acadêmicas, cívicas e políticas. Os 25 anos da Constituição Federal de 1988, que estabeleceu as bases da criação de um sistema de saúde único, universal, nacional, público e participativo, devem ser comemorados pela sociedade brasileira. Em particular, para lembrarmos, juntos, o fato de estarmos vivendo o mais longo período de franquias democráticas de nossa história republicana. É esse aspecto - a democracia, como substantivo que deve balizar o olhar sobre o passado, as análises do presente e os desafios do futuro quando nos debruçamos sobre nosso, ainda jovem, sistema de saúde.

A Constituição Cidadã e os 25 anos do Sistema de Saúde têm a virtude de nos fazer recordar as origens políticas do SUS nos seus vínculos com o processo de redemocratização do país. A construção do SUS foi constituinte e constituidora dele, conforme bibliografia assentada ${ }^{1,2}$. O texto reconhece avanços e denuncia muito apropriada e contundentemente, ecoando a literatura mais recente, os problemas atuais do SUS tais como subfinanciamento, a captura de dimensões da política por interesses privados, a precarização do trabalho e as desigualdades no acesso e na oferta 3,4. Contudo, as opções teóricas centradas num telos jamais alcançado - nunca avistado mas a ser perseguido apesar das perversões do capitalismo nacional e global, produz uma narrativa cujo futuro é o passado, é o que não aconteceu, o que não se realizou, num ânimo de retorno aos projetos originários. Ao transformar reforma sanitária - grafadas com letras maiúsculas - em categoria conceitual (semelhantes à de Revolução), o texto celebra e congela o passado inconcluso, e talvez não compreenda as mudanças que produziram um presente, considerado incômodo.

Apesar de minha simpatia em relação ao inconformismo com este presente - acirrado pelas manifestações de junho de 2013 - e pela empatia com a imaginação e compromisso generoso dos que propuseram e lutaram pela democracia e pela reforma do sistema de saúde três décadas atrás, cabe reconhecer que a Reforma Sanitária (com maiúsculas) está encerrada como conjunto de ideias e práticas políticas contextuais de um certo tempo de transição. Como movimento tornou-se, democraticamente, um movimento com menor protagonismo. Esse término tem razões virtuosas; foi resultado de seu próprio sucesso na proposição de uma agenda política e na montagem e arquitetura de um sistema de saúde sem paralelo ao sul (e ao norte, em alguns casos), e da conquista da democracia em 1985.

É resultado também do funcionamento das instituições democráticas nas últimas duas décadas. Um funcionamento com muitos problemas, advirto. Todavia, não transitamos mais de/para. Vivemos uma democracia. Convivemos com partidos políticos, governos estaduais e municipais, eleições rotineiras, liberdade de expressão, organizações sindicais e empresariais, movimentos sociais, conselhos, com um sistema judicial operando e funcionamento regular dos legislativos. O ordenamento federativo derivado de 1988 modificou os termos das negociações entre entes federativos e entre executivo e legislativo com profundos impactos sobre a saúde. Os loci decisórios se deslocaram. A dinâmica das políticas públicas (inclusas as de saúde) se transformou em relação à década de 1980, como indicam, com fartura de dados, trabalhos recentes 5,6. O SUS passou a fazer parte da rotina democrática pela qual projetos e interesses disputam as possibilidades de realização. Nem sempre são vitoriosos aqueles que são considerados, por alguns, eventualmente, virtuosos. Por exemplo, os programas de transferência de renda. Foram opções políticas, democráticas, criticáveis para alguns, mas não desvios "transformistas" de uma rota pré-estabelecida. O futuro desejável, em disputa e não antecipável, não está inscrito no passado, no que não se completou, no entanto pode estar num presente que exige, para ser escrutinado, uma compreensão da democracia brasileira, hoje. E estamos apenas no início...

1. Gerschman S. A democracia inconclusa. Um estudo da reforma sanitária brasileira. 2a Ed. Rio de Janeiro: Editora Fiocruz; 2011.

2. Escorel S. Reviravolta na saúde: origem e articulação do movimento sanitário. Rio de Janeiro: Editora Fiocruz; 1998.

3. Ocké-Reis CO. SUS: o desafio de ser único. Rio de Janeiro: Editora Fiocruz; 2012.

4. Machado CV, Baptista TWF, Lima LD. Políticas de saúde no Brasil: continuidades e mudanças. Rio de Janeiro: Editora Fiocruz; 2012.

5. Arretche M. Democracia, federalismo e centralização no Brasil. Rio de Janeiro: Editora FGV/Editora Fiocruz; 2012.

6. Cortês SV. Participação e saúde no Brasil. Rio de Janeiro: Editora Fiocruz; 2009. 